\title{
A Study on Teaching College English Reading from the Perspective of Invitational Rhetoric in China
}

\author{
Xiaomin $\mathrm{Yi}^{1} \&$ Mingyi Bai ${ }^{1}$ \\ ${ }^{1}$ School of Translation Studies, Shandong University, Weihai, China \\ Correspondence: Xiaomin Yi, School of Translation Studies, Shandong University, Weihai, Shandong, 264209 , \\ China. E-mail: 202017370@mail.sdu.edu.cn
}

Received: January 10, 2022

Accepted: February 17, 2022 Online Published: February 23, 2022

doi:10.5539/ijel.v12n2p70

URL: https://doi.org/10.5539/ijel.v12n2p70

\begin{abstract}
In this study, we explore the current situation of teaching college English reading in China and offer suggestions for improving it from the perspective of invitational rhetoric, mainly in terms of the three external conditions it advocates, safety, value and freedom, and its core, understanding. We distributed the questionnaire about the current situation of college English reading instruction to students majoring in English and analysed the results. Concerning the conditions of safety, the teachers respected students' views, but the students were not confident and were unwilling to participate in teacher-student interaction; therefore, teachers should create a safe external environment so that students trust them. Concerning the conditions of value, teachers allowed students to fully express their perspectives, and they prepared and conducted classroom activities from the students' standpoint. Regarding the conditions of freedom, students were selective in accepting teachers' views and formulated their own views, but when their views differed from those of teachers, few presented their opinions; teachers must acknowledge their weaknesses at the right time so that students can realise disagreeing with teachers is not equal to offending them. Regarding the conditions of understanding, teachers no longer aimed to instill knowledge; they paid more attention to students' understanding and encouraged them to form their own ideas while understanding students and accepting reasonable feedback.
\end{abstract}

Keywords: invitational rhetoric, English reading, college education

\section{Introduction}

In the past, in English reading classes in China, teachers' primary task was to teach language knowledge (e.g., grammar, vocabulary) and cultural knowledge, while students mainly took notes: 'Students are like empty containers, and teachers constantly fill the containers with knowledge' (Liu, 2021, p. 64). In this traditional teaching mode, students are accustomed to passively accepting teachers' interpretation of the text and seldom actively participate in class interaction. Instructors ignore students' understanding of the text and do not fully realise their subjectivity. As the educational system has developed in China, instructors have increasingly valued students' subjectivity. Invitational rhetoric also emphasises the importance of audience members. When rhetors offer their perspectives, they also welcome audience members to participate, react and share opinions. Thus, it is appropriate to apply invitational rhetoric to English reading classes in China to promote students' subjectivity and teacher-student interaction.

Since the introduction of invitational rhetoric in 1995, it has gained increasing attention in the American educational community, and various applied studies have emerged, such as studies on facilitating communication between teachers and students (Hicks-Goldston, 2011; Maher, 2002; Odartey, 2018), parents and children (Pariera \& Turner, 2020), teachers and parents (Modesti, 2012) and invitational pedagogy (Kirtley, 2014; Novak \& Bonine, 2009). Invitational rhetoric plays a meaningful role in communication, as well as in the medical (Make \& Lauver, 2022) and financial (Bathurst \& Galloway, 2018) fields. However, researchers have paid little attention to invitational rhetoric in the Chinese educational community. Zhang (2016) discussed the implication of invitational rhetoric for Chinese college education at a macro level, but researchers have not yet used invitational rhetoric to examine the current state of teaching English reading in China. Thus, we explore the current state of English teaching in Chinese colleges from the perspective of invitational rhetoric to identify problems and offer suggestions to address those problems. 


\section{Invitational Rhetoric}

\subsection{The Core: Understanding}

'Aristotelian thought teaches us that rhetoric is one's ability to find the available means of persuasion in any given situation' (Bizzell et al., 2001, p. 181, as cited in Munson, 2013, p. 9). Persuasion is the key word in classical rhetoric. In new rhetoric, Burke developed persuasion and proposed identification, but rhetors' goal is still to change others: 'Embedded in efforts to change others is a desire for control and domination, for the act of changing another establishes the power of the change agent over that other' (Foss \& Griffin, 1995, p. 3). However, the goal of rhetors in invitational rhetoric is wholly different: 'Invitational rhetoric is an invitation to understanding as a means to create a relationship rooted in equality, immanent value and self-determination' (Foss \& Griffin, 1995, p. 5). Rhetors invite audience members to enter their world to see it as they do. Audience members accept the invitation, attempt to understand the rhetors' perspectives and express their own opinions. Rhetors also treat audience members' opinions with respect and care and accept their opinions when such opinions are reasonable. Because of their joint efforts to solve the issue, they both have a deeper understanding of it. In addition to mutually understanding perspectives, they have a greater understanding of each other, which is crucial.

In classical rhetoric, 'the power of the rhetors over another is overt' (Foss \& Griffin, 1995, p. 3). 'Interaction processes have typically been characterized essentially and primarily in terms of persuasion, influence, and power' (Shepherd, 1992, p. 204). Rhetors' role 'may be best described as paternalistic' (Scott, 1991, p. 205). Rhetors hold an attitude like 'let me help you, let me enlighten you, let me show you the way' towards the audience (Gearhart, 1979, p. 195). Classical rhetoric is 'a rhetoric of patriarchy' (Foss \& Griffin, 1995, p. 4). Rhetors' experiences or perspectives are superior to those of audience members, who are considered less knowledgeable if they hold differing ideas. However, invitational rhetoric is 'committed to the creation of relationships of equality and to the elimination of the dominance and elitism that characterize most human relationships' (Foss \& Griffin, 1995, p. 4). Indeed, rhetors and audience members are equal. Rhetors do not have privilege, and their perspectives are not superior to those of audience members.

To 'result in mutual understanding of perspectives' and mutual understanding of each other, it is necessary to create external conditions where audience members can offer their perspectives (Foss \& Griffin, 1995, p. 10). The three external conditions are safety, value and freedom (Foss \& Griffin, 1995, p. 10).

\subsection{External Condition: Safety}

'The condition of safety involves the creation of a feeling of security and freedom from danger for the audience' (Foss \& Griffin, 1995, p. 10). The rhetor receives audience members' ideas and feelings with respect and care. The rhetor does not 'hurt, degrade, or belittle audience members or their beliefs' (Foss \& Griffin, 1995, p. 10). In this safe environment, audience members will trust the rhetor and thus actively offer their perspectives.

\subsection{External Condition: Value}

'The condition of value is the acknowledgment that audience members have intrinsic or immanent worth' (Foss $\&$ Griffin, 1995, p. 11). Every audience member has their own intrinsic and unique values which Benhabib (1992, p. 29) calls 'principle of universal moral respect' - 'the right of all beings capable of speech and action to be participants'. Audience members feel that the rhetor sees them as important individuals and appreciates their uniqueness. They feel the rhetor cares about them, understands their ideas, allows them to contribute to the issue and acknowledges their importance. Two ways of respecting audience members' value are 'absolute listening' (Gendlin, 1978, p. 116) and 'reversibility of perspectives' (Benhabib, 1992, p. 145). The former refers to not 'interrupt[ing], comfort[ing], or insert[ing] anything' when audience members speak about their experiences; the latter refers to 'reason[ing] from the standpoint' of audience members (Foss \& Griffin, 1995, p. 11).

\subsection{External Condition: Freedom}

Freedom refers to 'the power to choose or decide' (Foss \& Griffin, 1995, p. 12); both the rhetor and the audience have the power to 'speak up, to speak out' (Barrett, 1991, p. 148). The audience has the freedom to 'choose options from alternatives the rhetor offers' and to 'develop the options that seem appropriate to them' (Foss \& Griffin, 1995, p. 12). Rhetors raise their viewpoints is to inspire others and elicit ideas. Even if audience members do not adopt rhetors' specific perspectives and put forward different opinions, rhetors will not feel offended, disappointed or angry and will still value and appreciate audience members. 'Rhetors allow presuppositions to be challenged' (Foss \& Turner, 2020, p. 170). 


\section{Methodology}

\subsection{Research Design}

We used a questionnaire to examine the current situation of college English reading instruction in China. We conducted a pilot study with three classes and conducted the formal study with another four classes. We aimed to answer two research questions. First, in English reading classes, do teachers create the external conditions of safety, value and freedom? Second, in English reading classes, is mutual understanding realised between teachers and students? We drew the questionnaire items from four concepts: the three external environments that invitational rhetoric promotes, safety, value and freedom, and the core of invitational rhetoric, understanding.

\subsection{Sample}

We conducted the pilot study with 92 sophomore English majors (three classes) at a university in eastern China. After using the questionnaire, we interviewed five participants about their view of college English reading instruction and asked them for suggestions to improve the questionnaire. We conducted the formal study with 125 sophomore English majors (another four classes) at a university in eastern China. Before completing the questionnaire, we provided all participants with paper informed consent to ensure the participants' right to know, voluntariness, personal information security. After completing the questionnaire, we offered each participant a gel pen as compensation.

\subsection{Instrument}

For this study, we adopted a paper Likert scale questionnaire with multiple-choice items. We adjusted the items based on the analysis of the pilot study data and the post-test interviews. In the formal study, there were 17 items on the questionnaire. We tested the questionnaire for reliability and validity using SPSS 26.0.

\subsubsection{Reliability Test of the Questionnaire}

We analysed the data from 123 questionnaires for reliability using SPSS 26.0. Table 1 shows the reliability test results.

Table 1. Reliability test

\begin{tabular}{lll}
\hline Questionnaire & Cronbach's Alpha & Number of Items \\
\hline English Reading Class & .813 & 17 \\
\hline
\end{tabular}

The Cronbach's alpha value for the 17 items was 0.813 , which indicated the high validity of the questionnaire.

\subsubsection{Validity Test of the Questionnaire}

Before factor analysis, we conducted the Kaiser-Meyer-Olkin (KMO) test and Bartlett's test of sphericity. Only when the KMO value was $>0.5$ and the P-value $<0.05$ could we conduct the factor analysis (see Table 2).

Table 2. KMO and Bartlett's test

\begin{tabular}{lll}
\hline KMO and Bartlett's Test & & \\
\hline KMO measure of sampling adequacy & & .842 \\
\hline Bartlett's test of sphericity & Approx. chi-square & 928.657 \\
& df & 136 \\
& Sig. & .000 \\
\hline
\end{tabular}

The KMO value of the questionnaire was $0.842(>0.5)$, which indicates the correlation among the variables was relatively strong; the chi-square value of Bartlett's test of sphericity was 928.657 , and Sig. $=0.000$, which rejected the null hypothesis and indicated the data were suitable for factor analysis (Wu, 2010, p. 217). Table 3 lists the items measured and their corresponding components. 
Table 3. Rotated component Matrix

\begin{tabular}{|c|c|c|c|c|}
\hline \multirow[t]{2}{*}{ Item } & \multicolumn{4}{|c|}{ Component } \\
\hline & 1 & 2 & 3 & 4 \\
\hline 1. I am not afraid to speak in class. & 0.91 & & & \\
\hline 2. I enjoy speaking in class. & 0.84 & & & \\
\hline 3. Teachers receive my opinions with respect. & 0.52 & & & \\
\hline 4. Teachers sometimes degrade or belittle my opinions. & 0.55 & & & \\
\hline 8. Teachers receive my opinions with care. & 0.77 & & & \\
\hline 5. I can fully express my opinions in class. & & 0.52 & & \\
\hline 6. Teachers do not interrupt me when I express my opinions. & & 0.72 & & \\
\hline 7. Teachers reason from the standpoint of students. & & 0.61 & & \\
\hline 17. Teachers design the course from the standpoint of students. & & 0.82 & & \\
\hline 9. In class, I develop opinions that are appropriate to me. & & & 0.64 & \\
\hline 10. In class, I choose options from alternatives teachers offer instead of accepting all. & & & 0.82 & \\
\hline 11. When my views differ from those of teachers, I am brave enough to raise them. & & & 0.62 & \\
\hline 12. Teachers encourage students to come up with different ideas. & & & 0.55 & \\
\hline 13. Only teachers speak in class. & & & 0.65 & \\
\hline 14. Teachers accept reasonable feedback from students in class. & & & & 0.72 \\
\hline 15. The relationship between teachers and students is rooted in equality. & & & & 0.62 \\
\hline 16. The goal of teachers is only to persuade students to accept their opinions. & & & & 0.81 \\
\hline
\end{tabular}

Items 1, 2, 3, 4 and 8 belong to the first main component, safety. Items 5, 6, 7 and 17 belong to the second main component, value. Items 9, 10, 11, 12 and 13 belong to the third main component, freedom. Items 14, 15 and 16 belong to the fourth main component, understanding. The components we obtained were consistent with the concepts of the questionnaire, so the questionnaire had sound construct validity (Wu, 2010, p. 224).

\subsection{Data Collection}

We discarded invalid questionnaires (e.g., the handwriting was unclear, an answer was incomplete). In the end, we obtained 123 valid responses, then recorded and transcribed the data.

\subsection{Data Analysis}

The analytical framework is consistent with the two research questions. We analysed the constructs of safety, value and freedom, external conditions that invitational rhetoric advocates to answer the first research question, 'In English reading classes, do teachers create the external conditions of safety, value, and freedom?' We then analysed the fourth construct, understanding, the core tenet of invitational rhetoric, to answer the second research question, 'In English reading classes, is 'mutual understanding' realised between teachers and students?'

\section{Results and Discussion}

\subsection{External Condition: Safety}

From the perspective of invitational rhetoric, teachers should receive students' ideas and feelings with respect and care. They should not 'hurt, degrade, or belittle students' perspectives'; in this safe environment, students will trust teachers and thus will be unafraid and even enjoy speaking in class (Foss \& Griffin, 1995, p. 10). Table 4 lists the scores for the external condition of safety.

Table 4. External condition: safety

\begin{tabular}{llllll}
\hline Number & Item & $\begin{array}{l}\text { Strongly } \\
\text { Disagree }\end{array}$ & Disagree & $\begin{array}{c}\text { Undecided } \\
\text { Agree } \\
\text { Agree }\end{array}$ \\
\hline 1 & I am not afraid to speak in class. & 11 & 23 & 42 & 29 \\
2 & I enjoy speaking in class. & 19 & 26 & 40 & 18 \\
3 & Teachers receive my opinions with respect. & 0 & 2 & 18 & 14 \\
4 & Teachers sometimes degrade or belittle my opinions. & 64 & 36 & 41 & 4 \\
8 & Teachers receive my opinions with care. & 3 & 12 & 40 & 42 \\
\hline
\end{tabular}

We can see the teachers' perspective from items 3,4 and 8 and the students' perspective from items 1 and 2 . The students surveyed felt teachers respected (item 3) and cared about (item 8) their views without belittling them (item 4), but there was still a considerable problem among the students. Often, Chinese students are still afraid of answering questions (item 1) and do not like to answer them (item 2). There are two main reasons for this: the 
students do not yet trust the teacher enough, and the students lack confidence. To address the first problem, we suggest that teachers create a safer and more relaxed atmosphere, treat each student's speech sincerely, help students understand that there are only differences of opinion and there is no absolute right or wrong, give students emotional protection and win their trust. To solve the second problem, when students speak, teachers should listen carefully and provide affirmation so that students feel the joy of achievement. The more students feel this joy, the stronger their desire to perform will become. Therefore, students grow more confident.

\subsection{External Condition: Value}

Every student has intrinsic and unique value. Teachers should appreciate their uniqueness, acknowledge their importance and allow them to contribute to the issue. To practice absolute listening, when students express their opinions, teachers should not interrupt so that students can fully express their ideas. To practice reversibility of perspectives, teachers should reason from the students' standpoint; when they design courses, they should do the same. Table 5 outlines the external condition of value.

Table 5. External condition: value

\begin{tabular}{|c|c|c|c|c|c|c|}
\hline Number & Item & $\begin{array}{l}\text { Strongly } \\
\text { Disagree }\end{array}$ & Disagree & Undecided & Agree & $\begin{array}{l}\text { Strongly } \\
\text { Agree }\end{array}$ \\
\hline 5 & I can fully express my opinions in class. & 3 & 12 & 13 & 69 & 26 \\
\hline 6 & Teachers do not interrupt me when I express my opinions. & 5 & 7 & 14 & 50 & 47 \\
\hline 7 & Teachers reason from the standpoint of students. & 2 & 1 & 21 & 65 & 34 \\
\hline 17 & Teachers design the course from the standpoint of students. & 2 & 12 & 23 & 58 & 28 \\
\hline
\end{tabular}

In terms of absolute listening, the surveyed students reported teachers do not interrupt them when they talk (item 6), and thus students can adequately express their views (item 5). Students constitute the main body of teaching activities. Combined with their life experiences, they can provide new, unique and differing opinions. Teachers should allow students to freely put forward their own views on the text in a relaxed teaching atmosphere. By doing so, their interest in reading could be fully engaged, and teachers could cultivate their independent reading ability.

In terms of reversibility of perspectives, per the questionnaires, teachers do well in reasoning from the standpoint of students (item 7) and designing courses from the students' standpoint (item 17). When teaching a class, teachers should pay attention to students' abilities and cognitive characteristics. When students' answers are inaccurate, teachers should consider why they misunderstood from the students' point of view and then offer solutions. When designing curricula, teachers should consult students and take their interests into consideration. Instead of sticking to the units written in the textbook, teachers can restructure them from the learners' perspective to promote students' deep understanding.

\subsection{External Condition: Freedom}

Both teachers and students have the power to 'speak up, to speak out' in class (Barrett, 1991, p. 148). Students in class can express their views independently and freely. They do not need to fully and exactly accept teachers' views, can select from the views teachers offer and can develop their own perspectives. Teachers should encourage students to judge and think independently, express different ideas and gradually establish their own cognitive system. Table 6 lists the external condition of freedom.

Table 6. External condition: freedom

\begin{tabular}{|c|c|c|c|c|c|c|}
\hline Number & Item & $\begin{array}{l}\text { Strongly } \\
\text { Disagree }\end{array}$ & Disagree & Undecided & Strong & $\begin{array}{l}\text { Strongly } \\
\text { Agree }\end{array}$ \\
\hline 9 & In class, I develop opinions that are appropriate to me. & 0 & 4 & 35 & 54 & 30 \\
\hline 10 & $\begin{array}{l}\text { In class, I choose options from alternatives teachers offer } \\
\text { instead of accepting all. }\end{array}$ & 0 & 4 & 19 & 67 & 33 \\
\hline 11 & $\begin{array}{l}\text { When my views differ from those of teachers, I am brave } \\
\text { enough to raise them. }\end{array}$ & 13 & 29 & 41 & 29 & 11 \\
\hline 12 & $\begin{array}{l}\text { Teachers encourage students to come up with different } \\
\text { ideas. }\end{array}$ & 1 & 3 & 16 & 56 & 47 \\
\hline 13 & Only teachers speak in class. & 38 & 41 & 28 & 11 & 5 \\
\hline
\end{tabular}


In the survey, there were five questions concerning freedom: items $9,10,11,12$ and 13 . More students agreed with items 9 and 10. The ideal result would show that students are free to accept or reject the perspectives teachers offer in college reading classes and would have a high degree of freedom in forming their own appropriate views. The results also show that teachers encourage students to put forward different views in class (item 12). All answers reflect that in China, both students and teachers have the freedom to 'speak up, speak out' (Barrett, 1991, p. 148) in class (item 13). However, fewer students agreed with item 11, which shows that students were unwilling or afraid to put forward views that differ from those of teachers. In fact, they did not fully participate and get involved in class. 'Absolutist claims must be put aside', and rhetors should 'allow their own beliefs to be challenged' (Niebauer, 2017, p. 338). Hence, teachers must continue inspiring students to challenge their viewpoints and independently develop views. Maher (2002) stated teachers should be humble and admit their weaknesses, which will help change the situation where students passively accept teachers' pedagogy (pp. 89-90). Therefore, teachers should keep a low profile and admit their shortcomings so that they will not stifle students' freedom of expression and opinion and will give them freedom to think for themselves. Students will realise that presenting different views will not make teachers feel offended but rather appreciated. Then 'an atmosphere in which further creativity may flourish... [w]e become breathers/creators of free space' (Daly, 1984, p. 18). Both rhetors and audiences can achieve true freedom in classes.

\subsection{The Core: Understanding}

From the perspective of invitational rhetoric, teachers must form an equal relationship with students. They must change the dynamic in which teachers play the leading and dominant role, and students remain subordinate in the traditional spoon-feeding class; they must adjust the disproportionate communication mode between teachers and students in the traditional class mode. We advocate 'inviting a critical dialogue of possibility', not 'a domination of ideas rendering or reducing the listeners' standpoint' (Alexander \& Hammers, 2019, p. 7). However, we should point out a misunderstanding; people tend to think the most favourable way to achieve this reconciliation is to dilute teachers' power in the classroom, but this dilution often leads to teachers' complete denial of their own responsibilities. However, the purpose of inviting rhetoric for teaching is not to remove the power of teachers but to enhance the power of both sides (Maher, 2002, pp. 86-87). Table 7 outlines the core of understanding.

Table 7. The core: understanding

\begin{tabular}{|c|c|c|c|c|c|c|}
\hline Number & Item & $\begin{array}{l}\text { Strongly } \\
\text { Disagree }\end{array}$ & Disagree & Undecided & Strong & $\begin{array}{l}\text { Strongly } \\
\text { Agree }\end{array}$ \\
\hline 14 & $\begin{array}{l}\text { Teachers accept reasonable feedback from students in } \\
\text { class. }\end{array}$ & 1 & 0 & 15 & 66 & 41 \\
\hline 15 & $\begin{array}{l}\text { The relationship between teachers and students is } \\
\text { rooted in equality. }\end{array}$ & 0 & 7 & 17 & 60 & 30 \\
\hline 16 & $\begin{array}{l}\text { The goal of teachers is only to persuade students to } \\
\text { accept their opinions. }\end{array}$ & 32 & 39 & 22 & 22 & 8 \\
\hline
\end{tabular}

The surveyed students had more objections to item 16, which demonstrates that teachers no longer aim to instill knowledge. Most students agreed with items 14 and 15. The ideal results would show that teachers have changed the superior and condescending attitude common in the past and are now willing to accept students' opinions. In an equal relationship, students can understand teachers' viewpoints as well as form their own views, and teachers also accept reasonable feedback from students, thus achieving mutual understanding.

\section{Conclusion}

In this study, we used questionnaires to examine the current situation of English reading instruction in China from the perspective of invitational rhetoric. The results show that in terms of safety, teachers care about students' views to a great extent, but some problems still exist on the students' side. They are often afraid and unwilling to speak in class. Regarding value, teachers design courses from the students' perspective while considering students' cognitive abilities and interests, and they give students the freedom to speak freely; this phenomenon is positive. In terms of freedom, when students' views differ from those of teachers, some students dare not speak freely. Concerning understanding, the unequal relationship between teachers and students in the traditional teaching mode has changed. Teachers no longer aim to persuade students and will try to understand them, and students will do the same.

Furthermore, we offered suggestions for improving college English reading and teaching from the perspective of 
invitational rhetoric. First, teachers must create a safe and harmonious environment where students can speak actively and freely, respond to questions and answers from students with a positive attitude and refrain from belittling and underestimating them; these actions will relieve students of their fear of answering questions and thus foster their confidence when speaking in class. Second, teachers should praise each student for the merits of their answers and the value of their ideas. Meanwhile, they must ensure absolute listening and reversibility of perspectives. They should not interrupt or criticise students while listening to their answers so that students can freely express themselves. Furthermore, they should design course content and instruct students from the learners' perspective. They must emphasise students' interests and cognitive features to strengthen their interest in learning texts. Third, teachers should create a comfortable and free environment for students to fully achieve the subjective initiative, and they should admit their weaknesses at appropriate times to let students know that pointing out teachers' mistakes will not offend them. Fourth, when students try to understand teachers, teachers should try to understand students. Hence, both sides are empowered, and mutual understanding is realised.

\section{References}

Alexander, B. K., \& Hammers, M. (2019). An Invitation to Rhetoric: A Generative Dialogue on Performance, Possibility, and Feminist Potentialities in Invitational Rhetoric. Cultural Studies: Critical Methodologies, 19(1), 5-14. https://doi.org/10.1177/1532708617734011

Barrett, H. (1991). Rhetoric and Civility: Human Development, Narcissism, and the Good Audience. State University of New York Press.

Bathurst, R., \& Galloway, C. (2018). Invitational Discourse: Towards a Spirituality of Communication. Social Responsibility Journal, 14(4), 336-350. https://doi.org/10.1108/SRJ-05-2016-0089

Benhabib, S. (1992). Situating the Self: Gender, Community and Postmodernism in Contemporary Ethics. New York: Routledge.

Bizzell, P., Herzberg, B., \& Reames, R. (n.d.). The Rhetorical Tradition: Readings from Classical Times to the Present. New York: Bedford/St. Martin's.

Daly, M. (1984). Pure Lust: Elemental Feminist Philosophy. Boston: Beacon.

Foss, S. K., \& Griffin, C. L. (1995). Beyond Persuasion: A Proposal for an Invitational Rhetoric. Communication Monographs, 62(1), 1-18. https://doi.org/10.1080/03637759509376345

Foss, S. K., \& Turner, J. W. (2020). Challenges to the Enactment of Invitational Rhetoric in the Age of Mobile Communication Technologies. In S. K. Foss \& C. L. Griffin (Eds.), Inviting Understanding: A Portrait of Invitational Rhetoric (pp. 157-179). Lanham: Rowman \& Littlefield.

Gearhart, S. M. (1979). The Womanization of Rhetoric. Women's Studies International Quarterly, 2(2), 195-201. https://doi.org/10.1016/S0148-0685(79)91809-8

Gendlin, E. T. (1978). Focusing. New York: Everest.

Hicks-Goldston, C. L. (2011). Invitational Rhetoric and the Case for Service Learning. Sage Open, 1(3), 1-5. https://doi.org/10.1177/2158244011433604

Kirtley, S. (2014). Considering the alternative in Composition Pedagogy: Teaching Invitational Rhetoric with Lynda Barry's What It Is. Women's Studies in Communication, 37(3), 339-359. https://doi.org/10.1080/07491409.2014.946166

Liu, X. (2021). Alienation of College English Teaching: Causes and Responses. Journal of Xi'an International Studies University, 29(3), 63-67.

Maher, J. H. (2002). Invitational Interaction: A Process for Reconciling the Teacher/Student Contradiction. Rocky Mountain Review of Language and Literature, 56(1), 85-93. https://doi.org/10.2307/1348015

Make, J., \& Lauver, A. (2022). Increasing Trust and Vaccine Uptake: Offering Invitational Rhetoric as an Alternative to Persuasion in Pediatric Visits with Vaccine-Hesitant Parents (VHPs). Vaccine: X, 10. Advance online publication. https://doi.org/10.1016/j.jvacx.2021.100129

Modesti, S. (2012). Invitation Accepted: Integrating Invitational Rhetoric in Educational Contexts. Current Issues in Education, 15(1), 1-12. Retrieved from http://cie.asu.edu/ojs/index.php/cieatasu/article/view/904

Munson, D. (2013). Bridging the Gap: An Invitational Approach to Confucianism and Daoism. Master's dissertation, Syracuse University. Communication and Rhetorical Studies Theses. 4. Retrieved from https://surface.syr.edu/crs_thesis/4 
Niebauer, M. (2017). Dialogue or Proclamation? Communication Ethics and the Problem of Persuasion in Mission. Missiology: An International Review, 45(3), 336-348. https://doi.org/10.1177/0091829617696338

Novak, D., \& Bonine, B. (2009). Offering Invitational Rhetoric in Communication Courses. Communication Teacher, 23(1), 11-14. https://doi.org/10.1080/17404620802593013

Odartey, L. L. (2018). Invitational Rhetoric: An Engaged Pedagogy for Technical Communication. Master's dissertation, Michigan Technological University. https://doi.org/10.37099/mtu.dc.etdr/668

Pariera, K. L., \& Turner, J. W. (2020). Invitational Rhetoric between Parents and Adolescents: Strategies for Successful Communication. Journal of Family Communication, 20(2), 175-188. https://doi.org/10.1080/15267431.2020.1729157

Scott, R. L. (1991). The Necessary Pluralism of Any Future History of Rhetoric. Pre-Text: A Journal of Rhetorical Theory, 12(3-4), 195-209. Retrieved from https://eric.ed.gov/?id=EJ462341

Shepherd, G. J. (1992). Communication as Influence: Definitional Exclusion. Communication Studies, 43(4), 203-219. https://doi.org/10.1080/10510979209368373

Wu, M. (2010). Statistical Analysis of Questionnaires in Practice - the Operation and Application of SPSS. Chongqing University Press.

Zhang, Y. (2016). Invitational Pedagogy: Implication of Invitational Rhetoric for Chinese College Education. Modern College Education, 32(1), 105-111.

\section{Copyrights}

Copyright for this article is retained by the author, with first publication rights granted to the journal.

This is an open-access article distributed under the terms and conditions of the Creative Commons Attribution license (http://creativecommons.org/licenses/by/4.0/). 